\section{Defining response to anti-VEGF therapies in neovascular AMD}

Eye (2015) 29, 1397-1398; doi:10.1038/eye.2015.159

Correction to: Eye (2015) 29, 721-731; doi:10.1038/

eye.2015.48; published online 17 April 2015

Since the online publication of the above article, the authors have noted that the name of the ninth author was published incorrectly. The correct name is SP Kelly.

The authors have also noted that the conflict of interest statements were not complete. Below are the updated conflict of interest statements for each author:

Winfried Amoaku has provided consultancy services to Alcon, Alimera, Allergan, Bayer, Novartis and Thrombogenics. He has received travel grants from Alimera, Allergan, Bayer and Novartis, and honoraria for lectures from Allergan and Novartis. He has participated in clinical trials for which his institution has received funding from Allergan, Novartis and Pfizer. His institution has further received research grants from Allergan and Novartis for non-clinical studies, and CentreVue (Italy) for clinical studies.

Usha Chakravarthy's institution has received payments from Allergan, Bayer, Notal, and Novartis for research projects. She has participated in Advisory Boards held by Alimera, Allergan, Roche and Novartis in the past three years with personal remuneration.

Richard Gale has been a consultant for Novartis, Allergan and Bayer. He has received educational/travel grants from Allergan and Novartis, and his institution has participated in clinical studies sponsored by Novartis, Bayer and Allergan.

Mike Gavin has received fees for lecture from Bayer and Novartis, and participation in Advisory Boards of Alimera, Allergan, Bayer and Novartis.
WM Amoaku, U Chakravarthy, R Gale, M Gavin, F Ghanchi, J Gibson, S Harding, RL Johnston, SP Kelly, A Lotery, S Mahmood, G Menon, S Sivaprasad, J Talks, A Tufail and Y Yang

He has received educational travel grants from Bayer and Novartis. His institution has also received research funding from Novartis.

Faruque Ghanchi has received honoraria for lectures, and educational travel grants from Bayer and Novartis, as well as honoraria for Advisory Boards from Bayer and Novartis. He and his employers have participated in research funded by Novartis and Bayer.

Jonathan Gibson has received fees for Advisory Board attendances and travel grants for attending conferences from Novartis UK, Bayer Health, Alimera, Allergan UK, and his employer (Aston University) has received a research grant from Novartis UK.

Simon Harding has not received any personal payments for advisory boards, lecture fees of education travel grants for the past 3 years. His department/employer has received grant support for research from Novartis and Bayer.

Robert L Johnson has received honoraria for lectures from Alcon and Novartis, educational travel grants from Alcon, Bayer, and Novartis, as well as honoraria for Advisory Boards from Alcon, Bayer, and Novartis.

Simon Kelly has received honoraria for consultancy from Novartis and Bayer, and conference travel grants from Alcon, Bayer, and Novartis. He has also received honoraria for lectures from Novartis. His employer has undertaken research sponsored by Bayer and Novartis.

Andrew Lotery has attended Advisory Board meetings for which he has received honoraria, and received travel support to attend educational meetings from Novartis and Bayer. His institution has received research grant funding from Allergan, Bayer, Novartis, and Roche. 
Sajjad Mahmood has received honoraria for lectures, and educational travel grants from Bayer, and Novartis, as well as honoraria for Advisory Boards from Bayer and Novartis. He and his employers have participated in research funded by Novartis and Bayer.

Geeta Menon has attended Advisory Boards of Alcon, Allergan, Bayer, and Novartis. She has received travel grants from Bayer and Novartis. Her institution has received research grants from Allergan, Alcon, Bayer, and Novartis Bayer for clinical trials.

Sobha Sivaprasad has participated in Advisory Boards, and received educational travel grants and speaker fees from Bayer, Novartis, Allergan, and Roche. Her institution has received research grant funding from Allergan, Bayer, Novartis, and Roche.
James Talks has attended Advisory Boards of Allergan, Bayer, and Novartis, and received travel grants from Bayer, as well as, lecture fees. He has been involved in clinical trials sponsored by Novartis and Bayer.

Adnan Tufail has participated in Advisory Boards, from Alcon, Allergan, Advanced Bayer, Genentech, Heidelberg Engineering, Notal, Novartis, OCTA Therapeutics, Pfizer, Roche, and Thrombogenics. His institution has received research grant funding from Allergan, Bayer, Novartis, and Roche.

Yit Yang has received honoraria from Alcon, Allergan, Bayer, Novartis, Thrombogenics, Genentech, Pfizer, Heidelberg UK.

The authors apologise for any inconvenience caused by this error. 